BIOMEDICAL AND BIOSOCIAL ANTHROPOLOGY
$\begin{gathered}\text { Official Journal of the International Academy } \\ \text { of Integrative Anthropology } \\ \text { journal homepage: http://bba-journal.com }\end{gathered}$

\title{
Changes in the histostructure of the lungs of old rats under conditions of persistent hyperhomocysteinemia
}

Samborska I. A.

National Pirogov Memorial Medical University, Vinnytsya, Ukraine

\section{ARTICLE INFO}

Received: 6 November 2020

Accepted: 8 December 2020

UDC: $616.24: 577.112 .386: 599.323 .45$

\section{CORRESPONDING AUTHOR}

e-mail: samborska1990@gmail.com Samborska I. A.
To date, homocysteine has been found to be an important biomarker of bronchopulmonary pathology, including COPD. The increase in its concentration in the blood plasma causes the start of free radical processes and the production of reactive oxygen species, which activate lipid peroxidation in lung tissue. In addition, the activation of endoplasmic reticulum stress with increasing homocysteine levels is the main reason for triggering apoptosis of alveolocytes. The aim of the research is to study the features of lungs histostructure in old rats under conditions of hyperhomocysteinemia. The experimental study was performed on 20 white nonlinear old (24-26 months) male rats. During the experiment, the animals were divided into two groups - control and experimental. Simulation of the state of persistent hyperhomocysteinemia was achieved by administering to rats of experimental group thiolactone homocysteine at a dose of $200 \mathrm{mg} / \mathrm{kg}$ body weight intragastrally for 60 days. Histological specimens were studied using an SEO CCAN light microscope and photo-documented using a Vision CCD Camera with an image output system from histological specimens. In elderly animals under conditions of experimental hyperhomocysteinemia develop severe destructivedegenerative changes in the lungs. Significant remodeling of the vascular bed, bronchi, inflammatory manifestations, enlargement of dis- and atelectasis and emphysematically altered alveoli of the respiratory lungs, violation of the alveolar walls, with the release of blood cells into the alveolar space and the formation of small diapedetic hemorrhages. The development of perivascular, peribronchial and interstitial sclerosis is characteristic.

Keywords: hyperhomocysteinemia, atelectasis, emphysema, sclerosis.

\section{Introduction}

Homocysteine is a natural metabolite formed from the amino acid methionine. Under normal conditions, its level in blood plasma is about 5-15 $\mu \mathrm{mol} / /$ [15]. However, disorders of homocysteine metabolism, characterized by an increase in its concentration above $15 \mu \mathrm{mol} / /$, causes the development of hyperhomocysteinemia syndrome. The latter, according to the literature, is closely correlated with pathologies of the cardiovascular and respiratory systems, thrombotic complications, neurodegenerative processes, etc. [1, 21]. Thus increase in level of homocysteine in blood, in the specified conditions, can be both the reason, and a consequence of the listed pathological states. Increased homocysteine concentration occurs when the synthesis of methionine and cysteine, which develops due to deficiency of vitamins B6, B9 and B12, as well as genetic polymorphism of certain enzymes - methylenetetrahydrofolate reductase, cystathionine- $\beta$-synthase $[4,9,13,17]$.
The pathogenesis of the negative impact of hyperhomocysteinemia on the human body is being actively studied. Thus, for a number of decades it is undeniable that elevated levels of homocysteine are one of the main risk factors for the occurrence and progression of numerous pathological conditions. It is known to damage endothelium walls of blood vessels, activates the blood coagulation system, increases the myotoxicity of smooth muscle cells, interacts and competes with glutamate receptors of neurons, megakaryocytes, erythrocytes, lymphocytes, neutrophils, cardiomyocytes. In addition, hyperhomocysteinemia is associated with the development of oxidative stress, inflammation and fibrosis $[3,5,7]$.

The influence of homocysteine on the peculiarities of the histostructure of the respiratory system is still insufficiently studied. However, to date, it has been established that it is an important biomarker of bronchopulmonary pathology, 
including COPD. The increase in its concentration in blood plasma causes the start of free radical processes and the production of reactive oxygen species, which in lung tissue activate lipid peroxidation due to the presence of a significant amount of unsaturated fatty acids. It is also known that homocysteine is able to affect the structure and function of proteins through the process of their homocysteine. The latter occurs during post-translational modifications of proteins in the endoplasmic reticulum and can cause misfolding, organelle overload and the development of stress. Stress of the endoplasmic reticulum in lung tissue under conditions of hyperhomocysteinemia triggers signaling pathways of cell apoptosis, so it is a common cause of alveolocyte death [11, 14, 19].

At present, domestic and foreign scientometric sources have an extremely limited number of studies on histological changes in lung tissue in hyperhomocysteinemia, and some fragmentary data do not fully outline this problem.

The aim of the research is to study the features of the histostructure of the lungs of old rats under conditions of hyperhomocysteinemia.

\section{Materials and methods}

The experiments were performed on 20 white nonlinear old (24-26 months) male rats. During the experiment, the animals were divided into two groups - control and experimental. Simulation of persistent hyperhomocysteinemia was achieved by administering to rats the experimental group of thiolactone homocysteine at a dose of $200 \mathrm{mg} / \mathrm{kg}$ body weight intragastrally for 60 days [16]. Animals were decontaminated by decapitation under thiopental anesthesia [6]. For microscopic examination, pieces of lungs were taken from pre-weighed animals of all groups. The pieces were fixed in $10 \%$ formalin solution, while the duration of exposure did not exceed 1 2 days. The applied fixing solution prevents the process of autolysis and stabilizes cells and tissues for their further processing and use in staining procedures. Next, the pieces were dehydrated in alcohols of increasing concentration and poured into paraffin blocks. The sections made with a thickness of $4-5 \mu \mathrm{m}$ were stained with hematoxylin and eosin and methylene blue [2, 10]. Histological specimens were studied using an SEO CCAN light microscope and photo-documented using a Vision CCD Camera with an image output system from histological specimens.

\section{Results}

Microscopic examinations of the lungs of experimental animals of old age on the background of hyperhomocysteinemia revealed significant inflammatory, destructive changes and characteristic sclerotic changes of blood vessels, bronchi, respiratory tract. Changes in the bronchi were characterized by remodeling of all wall membranes. The mucous membrane undergoes significant alternative changes, in the epithelial plate the cells had fuzzy membranes of plasmalemma, dystrophically altered, enlightened

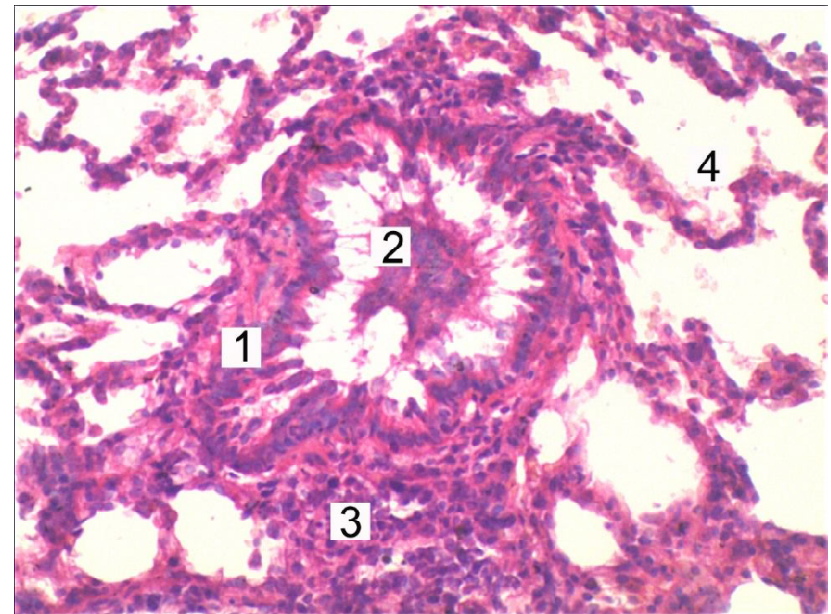

Fig. 1. Microscopic changes in the lungs of an elderly animal under conditions of hyperhomocysteinemia. Deformed bronchial wall (1), mucosal detritus in the lumen (2), leukocyte infiltration of the adventitia (3), respiratory department (4). Staining with hematoxylin and eosin. $x 200$.

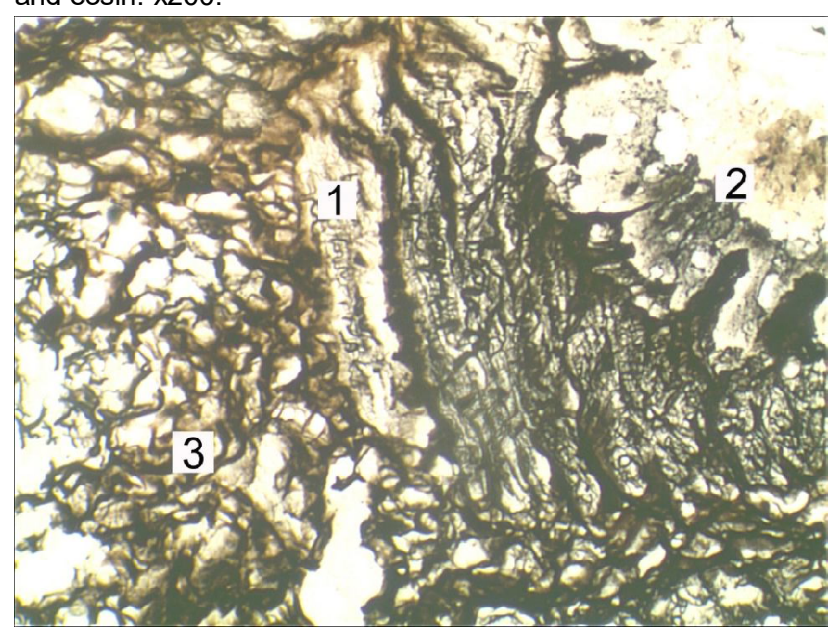

Fig. 2. Microscopic condition of the lung of an old rat impregnated with silver nitrate under conditions of hyperhomocysteinemia. Disorganization of reticular fibers of the bronchial wall (1), lumen with mucous content (2), argyrophilic collagen fibers of adventitia (3). Gordon and Sweets staining method X200.

cytoplasm, hyperchromic, pyknotic nuclei. Desquamation of epitheliocytes into the bronchial lumen was determined. The bronchi were deformed due to atrophy or hypertrophy of the muscle plate, especially the small bronchi and bronchioles, and due to inflammatory and sclerotic changes. Volumetric accumulations of mucosal detritus were determined in their lumens (Fig. 1).

Impregnation with silver salts reveals an increase in the content of fibrous components in the bronchial wall, especially the adventitial membrane, which have intense argyrophilia, which leads to peribronchial sclerosis (Fig. 2).

Histologically at this time of the experiment it was found that the vessels are characterized by moderate blood supply, but often found in the lumens formed clots. The wall is destructively changed, deformed. In the endothelium of the 


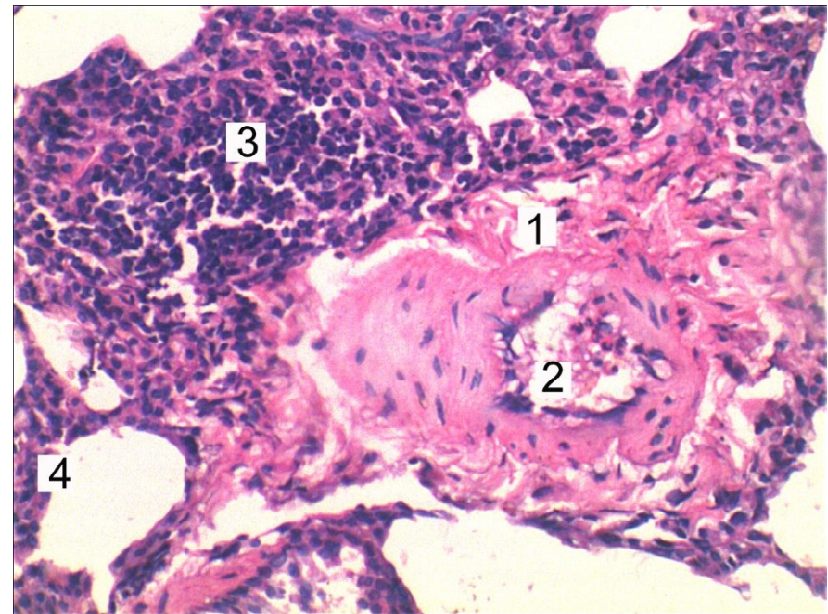

Fig. 3. Histological changes in the lungs of an elderly animal under conditions of hyperhomocysteinemia. Dystrophically altered artery wall (1), lumen (2), leukocyte infiltrate (3), respiratory tract (4). Staining with hematoxylin and eosin. x200.

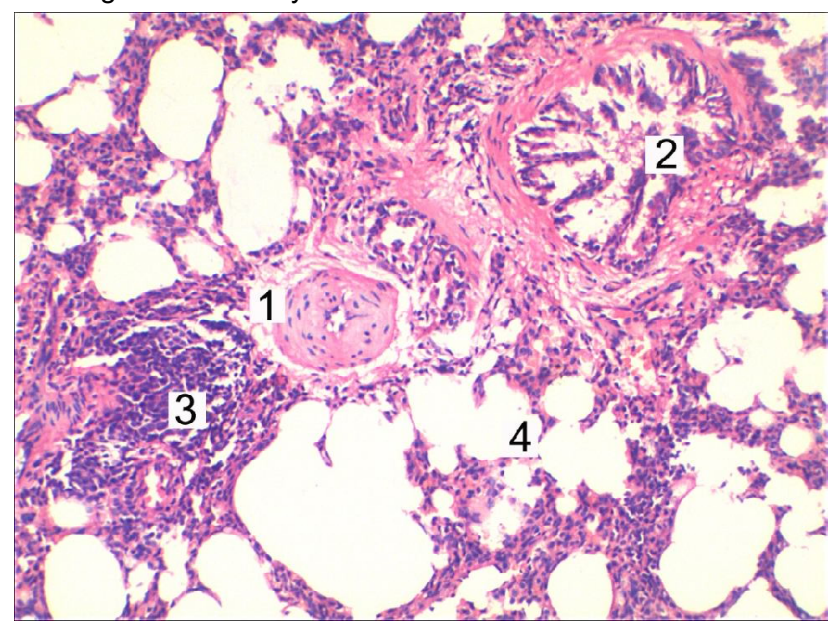

Fig. 4. Histological changes in the lungs of an elderly animal under conditions of hyperhomocysteinemia. Artery of small caliber "closing type" with hypertrophy of the media (1) deformed, destructively altered bronchus (2), leukocyte infiltrate (3), respiratory department (4). Staining with hematoxylin and eosin. $x 100$.

intima there are deformation, homogenization of the inner elastic membrane, pyknosis of endothelial nuclei and desquamation into the lumen of the vessel of endothelial cells with the exposure of the basement membrane. Smooth media myocytes are swollen, homogenized, dystrophically altered, contain hyperchromic nuclei. There are small vessels in the body, the so-called "closing" arteries, in which the media is thickened due to hyperplasia of smooth muscle cells, the lumen of which is narrow, slit-like (Fig. 3). Manifestations of the inflammatory nature of the vascular wall were determined by leukocyte infiltration of the entire thickness, mostly adventitia (Fig. 4).

Also during this period of the experiment revealed pronounced manifestations of sclerosis of the wall, mostly adventitia, which was manifested by active proliferation of fibroblasts and the growth of reticular and, to a greater extent, collagen fibers, which have a bright argyrophilia (Fig. 5).

The vessels of the hemomicrocirculatory tract were also significantly altered, manifested by heterogeneity. Venules were characterized by stagnation, stasis, erythrocyte sludge, thrombosis. Endotheliocytes are dystrophically altered, contain pyknotic nuclei that protrude into the lumen of the vessel. The arterioles had a thickened, destructively altered wall and a narrowed, spasmodic lumen. Significant perivascular leukocyte infiltration was detected. Hemocapillaries are also characterized by plethora, stasis and sludge, the basement membrane is homogeneous, swollen, indistinctly contoured, dystrophically altered endothelium.

Reorganization of vessels and bronchi is accompanied

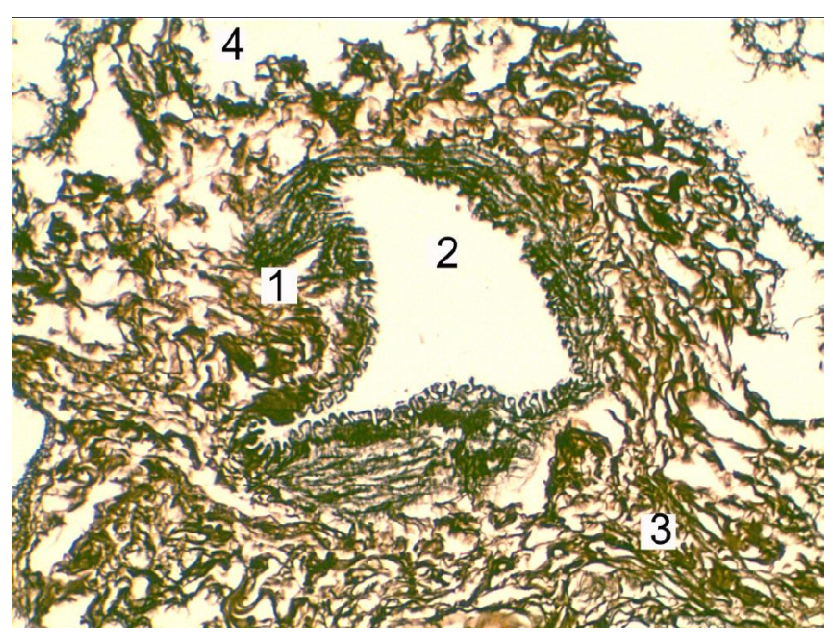

Fig. 5. Microscopic condition of the lung of an old rat impregnated with silver nitrate under conditions of hyperhomocysteinemia. Deformation and destruction of the artery wall (1), lumen of the vessel (2), argyrophilic collagen fibers of the adventitia (3), respiratory department (4). Gordon and Sweets staining method. $\mathrm{x} 200$

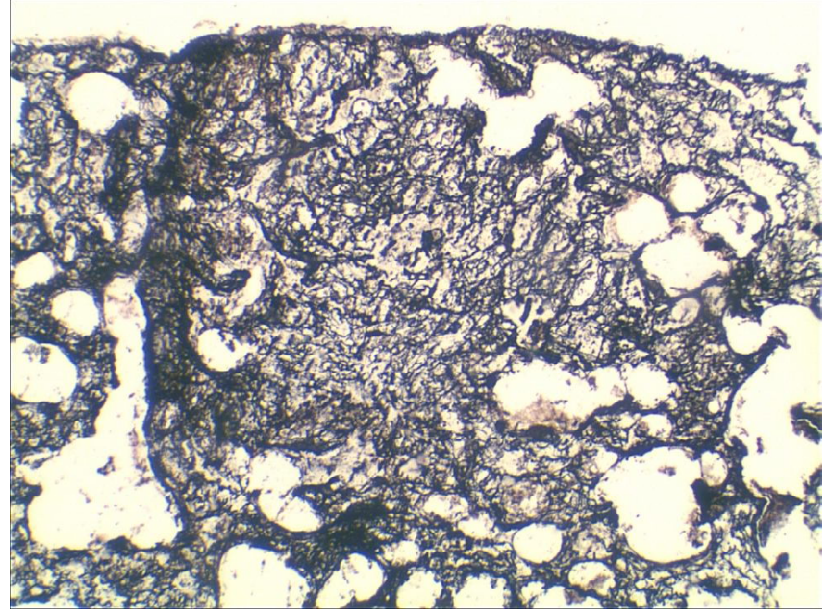

Fig. 6. Microscopic condition of the lungs of old rats when impregnated with silver nitrate under conditions of hyperhomocysteinemia. Growth in the respiratory department of small argyrophilic reticular and collagen fibers. Gordon and Sweets staining method. $\mathrm{x} 100$. 


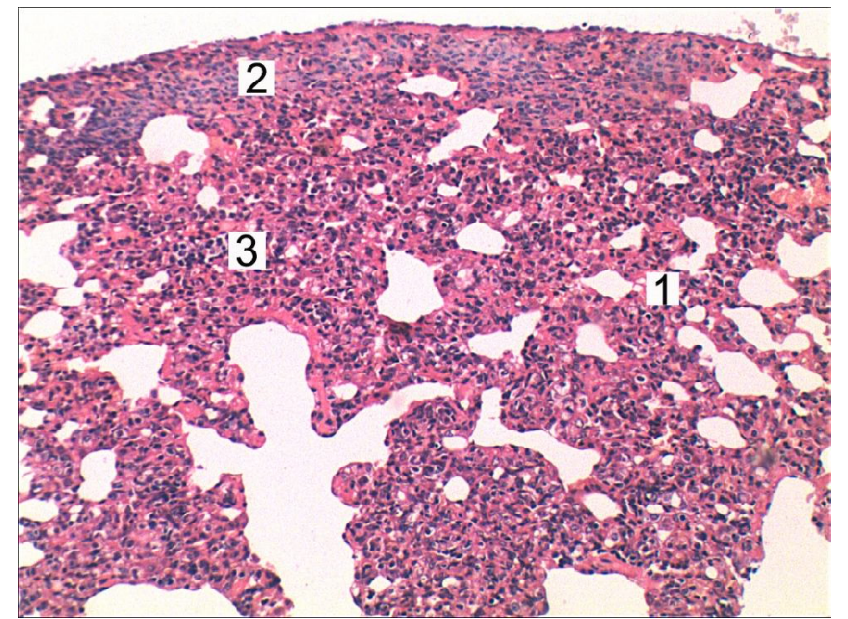

Fig. 7. Histological changes in the lungs of an elderly animal under conditions of hyperhomocysteinemia. Areas of dis- (1) and atelectasis (2), with leukocyte infiltration (3). Staining with hematoxylin and eosin. $\mathrm{x} 200$.

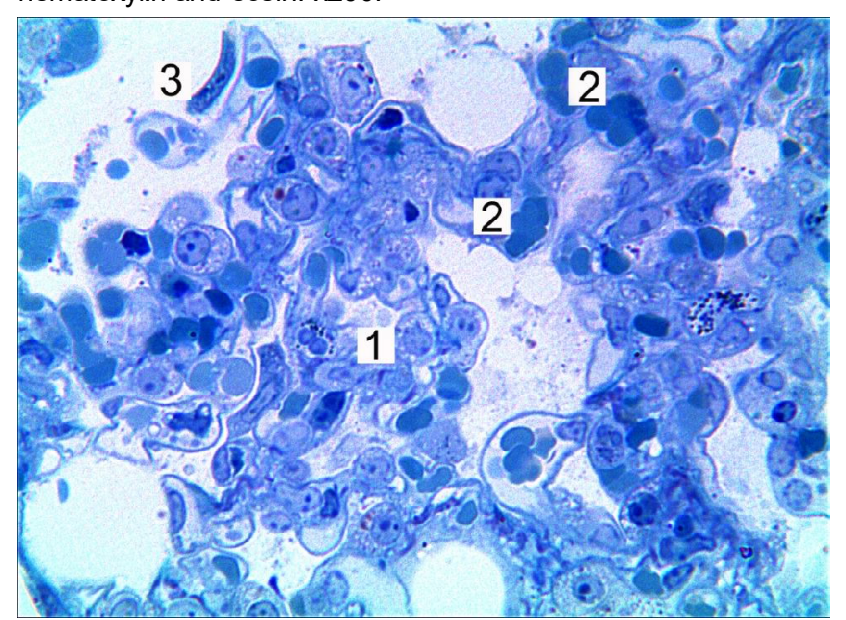

Fig. 8. Microscopic changes in the lungs of an elderly animal under conditions of hyperhomocysteinemia. Areas of dis- and atelectasis (1), blood-filled hemocapillaries (2), alveolar macrophages (3) of the respiratory department. Semi-thin slice. Methylene blue staining. $\mathrm{x} 400$.

by changes in the parenchyma of the organ. Lung tissue is heterogeneous, dominated by areas of dis- and atelectasis, which show the growth of collagen fibers, which are clearly defined by impregnation with silver salts, which leads to widespread mosaic fibrosis of the respiratory tract (Fig. 6). Emphysematically dilated alveoli are present mainly in the subpleural areas. Areas of unchanged histostructure of lung tissue are relatively small. Areas of damage to the interalveolar septa are detected, with the release of formed blood elements into the lumen of the alveoli. There are small interstitial and focal hemorrhages.

Histo-leukocyte infiltration is present in almost all fields of view in the components of the respiratory department of the lungs (Figs. 7, 8). Numerous young and actively phagocytic macrophages were found in the lumens of the alveoli.

\section{Discussion}

In the modern world, interest in the problem of hyperhomocysteinemia and its importance in the mechanisms of occurrence and progression of diseases of the respiratory system is growing significantly. In recent years, numerous clinical studies have shown that homocysteine is a predictor of COPD. A significant increase in its concentration in the blood causes a worsening of the disease, the development of complications or comorbid pathologies, mainly from the cardiovascular system. The causes of hyperhomocysteinemia in COPD are not clearly established, but it is characteristic that this group of patients is deficient in vitamins B6, B9 and B12, which act as important cofactors in biochemical reactions of homocysteine utilization. According to scientists, one of the mechanisms of pathogenetic action of homocysteine under these conditions is the development of oxidative stress. This fact is explained by the significant depletion of the antioxidant defense system, which in patients manifests itself in the form of a significant decrease in the levels of reduced and total glutathione [12].

According to other authors, not only the level of homocysteine but also the balance in the $\mathrm{H}_{2} \mathrm{~S}$ / homocysteine system plays an important role in the course of diseases of the respiratory system. It is known that $\mathrm{H}_{2} \mathrm{~S}$ has anti-inflammatory, antioxidant properties, prevents the development of fibrosis and damage to lung tissue. Patients with bronchopulmonary pathology show a decrease in the concentration of $\mathrm{H}_{2} \mathrm{~S}$, and its levels are negatively correlated with the severity of the disease. Under these conditions, the presence of risk factors such as overweight, dyslipidemia, smoking, old age and hyperhomocysteinemia create the basis for the activation of free radical processes and the development of oxidative stress. A significant increase in the concentration of homocysteine is the cause of inflammatory processes in the smooth muscle cells of vascular walls, endothelial damage. These changes not only worsen the course of the disease, but also become the basis of severe cardiovascular complications, including heart attacks or strokes [8].

Recent studies on mice have shown that persistent experimental hyperhomocysteinemia combined with exposure to animal smoke is the cause of severe pulmonary emphysema, which is seen in histological studies as significant alveolar cell death. The latter is probably due to the triggering of endoplasmic reticulum stress and apoptosis signaling pathways [18].

It is also relevant that hyperhomocysteinemia and vitamin B9 deficiency are considered risk factors for lung cancer. According to researchers, the pathogenesis of this phenomenon is a violation of DNA methylation. One of the important donors of metal groups is Sadenosylmethionine, but its level is significantly reduced under conditions of folate deficiency, changes in the mechanisms of homocysteine metabolism and, accordingly, an increase in the concentration of the latter. 
There is a violation of methylation of cytosine in DNA, violation of oncogene suppression and activation of malignant cell transformation [20].

\section{Conclusion}

In elderly animals under conditions of experimental hyperhomocysteinemia develop severe destructivedegenerative changes in the lungs. Significant remodeling of the vascular bed, bronchi, inflammatory manifestations,

\section{References}

[1] Azad, M. A. K., Huang, P., Liu, G., Ren, W., Tekebrh, T., Yan, W., ... \& Yin, Y. (2018). Hyperhomocysteinemia and cardiovascular disease in animal model. Amino Acids, 50(1), 3-9. doi: 10.1007/ S00726-017-2503-5

[2] Bahrii, M. M., Dibrova, V. A., Popadynets, O. H. \& Hryshchuk, M. I. (2016). Методики морфологічних досліджень [Methods of morphological research]. Вінниця: Нова Книга - Vinnytsia: New Book.

[3] Behera, J., Tyagi, S. C., \& Tyagi, N. (2019). Hyperhomocysteinemia induced endothelial progenitor cells dysfunction through hypermethylation of CBS promoter. Biochem Biophys Res Commun, 510(1), 135-141. doi: 10.1016/j.bbrc.2019.01.066

[4] Burdenny` j, A. M., Loginov, V. I., Zavary’kina, T. M., Braga, E’. A., \& Kubatiev, A. А. (2017). Молекулярно-генетические нарушения генов фолатного и гомоцистеинового обмена в патогенезе ряда многофакторных заболеваний [Molecular genetic disorders of folate and homocysteine metabolism genes in the pathogenesis of a number of multifactorial diseases]. Генетика - Genetics, 53(5), 526-540.

[5] Chen, Y., Zhang, H., Liu, E., Xu, C., \& Zhang, Y. (2016). Homocysteine regulates endothelin type $B$ receptors in vascular smooth muscle cells. Vascul Pharmacol, (87), 100-109. doi: 10.1016/j.vph.2016.08.011

[6] Dobrelia, N. V., Boitsova, L. V. \& Danova, I. V. (2015). Правова базадля проведення етичної експертизи доклінічних досліджень лікарських засобів з використанням лабораторних тварин [Legal basis for ethical examination of preclinical studies of drugs using laboratory animals]. Фармакологія та лікарська токсикологія - Pharmacology and drug toxicology, (2), 95100.

[7] Faversani, J. L., Hammerschmidt, T. G., Sitta, A., Deon, M., Wajner, M., \& Vargas, C. R. (2017). Oxidative stress in homocysteinuria due to cystathione $\beta$-synthase deficiency: findings in patients and in animal model. Cell Mol Neurobiol, 37(8), 1477-1485. doi: 10.1007/s10571-017-0478-0

[8] He, Y., Liu, S., Zhang, Z., Liao, C., Lin, F., Yao, W., ... \& Chen, Y. (2017). Imbalance of endogenous hydrogen sulfide and homocysteine in chronic obstructive pulmonary disease combined with cardiovascular disease. Front Pharmacol, (8), 624. doi: 10.3389/fphar.2017.00624

[9] Hiraoka, M., \& Kagawa, Y. (2017). Genetic polymorphisms and folate status. Congenit Anom (Kyoto), 57(5), 142-149. doi: 10.1111/cga.12232

[10] Horalskyi, L. P., Khomych, V. T., \& Kononskyi, O. I. (2011). Основи гістологічної техніки і морфоорункціональні методи досліджень у нормі та при патології [Fundamentals of histological technique and morphofunctional research methods in normal and pathology]. Житомир: Полісся Zhytomyr: Polissya.

[11] Jakubowski, H. (2019). Homocysteine modification in protein enlargement of areas of dis- and atelectasis and emphysematically altered alveoli of the respiratory lungs, violation of the alveolar walls, with the release of blood cells into the alveolar space and the formation of small diapedes. Activation of fibroblasts is manifested by a pronounced collagen formation, which causes perivascular, peribronchial and interstitial sclerosis, which has a significant negative impact on the process of gas exchange in the lungs.

structure / function and human disease. Physiol Rev, 99(1), 555-604. doi: 10.1152/physrev.00003.2018

[12] Khan, N. A., Saini, H., Mawari, G., Kumar, S., Hira, H. S., \& Daga, M. K. (2016). The effect of folic acid supplementation on hyperhomocysteinemia and pulmonary function parameters in chronic obstructive pulmonary disease: a pilot study. J Clin Diagn Res, 10(11), 17-21. doi: 10.7860/JCDR/2016/21322.8927

[13] Kim, J., Kim, H., Roh, H., \& Kwon, Y. (2018). Causes of hyperhomocysteinemia and its pathological significance. Arch Pharm Res, 41(4), 372-383. doi: 10.1007/s12272-018-1016-4

[14] Liu, Z., Wang, H., Guan, L., \& Zhao, B. (2015). Regulatory effects of hydrogen sulfide on alveolar epithelial cell endoplasmic reticulum stress in rats with acute lung injury. World $\mathrm{J}$ Emerg Med, 6(1), 67-73. doi: 10.5847/wjem.j.1920-8642.2015.01.012

[15] Lutsiuk, M. B., Zaichko, N. V., Hryhorieva, H. S., Konakhovych, M. A., Artemchuk, M. A., Pentiuk, N. O., ... \& Postovitenko, K. P. (2013). Синдром гіпергомоцистеїнемії: причини виникнення, способи профілактики та лікування [Hyperhomocysteinemia syndrome: causes, methods of prevention and treatment]. Рациональная фрармакотерапия - Rational pharmacotherapy, 29(4), 55-60.

[16] Medvedev, D. V., Zvyagina, V. I., \& Fomina, M. A. (2014). Способ моделирования тяжелой формы гипергомоцистеинемии у крыс [Method for modeling severe hyperhomocysteinemia in rats]. Российский медико-биологический вестник имени академика И. П. Павлова - Russian medical and biological bulletin named after academician I.P. Pavlov, (4), 42-46.

[17] Moretti, R. (2019). Homocysteine: new aspects of an ancient enigma. Cardiology, 144(1-2), 36-39. doi: 10.1159/000501997

[18] Nakano, H., Inoue, S., Igarashi, A., Tokairin, Y., Yamauchi, K., Kimura, T., ... \& Shibata, Y. (2021). Effect of hyperhomocysteinemia on a murine model of smoke-indiced pulmonary emphysema. Research Square. https: www. researchsquare.com/article/rs-249722/v1. doi: 10.21203/rs.3rs-249722/v1

[19] Silla, Y., Varshney, S., Ray, A., Basak, T., Zinelly, A., Sabaresh, V., ... \& Sengupta, S. (2019). Hydrolysis of homocysteine thiolactone results in the formation of protein-cys-S-Shomocysteinylation. Proteins, 87(8), 625-634. doi: 10.1002/ prot.25681

[20] Yang, J., Li, H., Deng, H., \& Wang, Z. (2018). Association of onecarbon metabolism-related vitamins (folate, B6, B12) homocysteine and methionine with the risk of lung cancer: systematic review and meta-analysis. Front Oncol, (8), 493. doi: 10.3389/fonc. 2018.00493

[21] Zaichko, N. V., Lutsiuk, M. B., \& Hryhorieva, H. О. (2012). Гinepгомоцистеїнемія: медико-соціальні та фрармакологічні аспекти [Hyperhomocysteinemia: medical, social and pharmacological aspects]. Фармацевтичний кур'єр Pharmaceutical courier, (9), 30-35. 